\title{
legelivet
}

På disse sidene i Tidsskriftet - legelivet - finner du stoff om legers liv.

Her er det presentasjon av arbeidssteder, nyhetssaker, nye doktorgrader,

nye spesialister og minneord. Alt samlet på ett sted - så du kan følge enda bedre med.

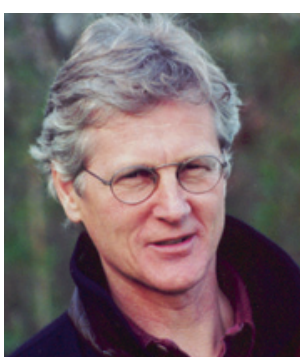

Karl Otto Nakken Foto: Privat

Karl Otto Nakken (f. 1945) er lege ved Nevroklinikken, Oslo universitetssykehus.

\section{Fag og legerolle i stadig endring}

\author{
I det siste møtet i doktorklubben lurte et medlem på hvilke medisinske \\ fremskritt vi anså som viktigst i den tiden vi hadde vært leger.
}

Blant våre åtte medlemmer var det ikke overraskende åtte oppfatninger. Svarene bar preg av en grov overvurdering av eget fagfelts betydning. I vår tid har ulcussykdommen gått fra å være en livsstilssykdom til en infeksjonssykdom, enkelte kreftformer har fått en langt bedre prognose enn før, innenfor bildedannende teknikker og intervensjonsradiologi har det det skjedd dramatiske endringer, og epigenetikk og sekvensering av DNA må sies å ha representert et paradigmeskifte.

Utforskingen av kroniske sykdommer som diabetes, astma, multippel sklerose, Alzheimers sykdom og schizofreni syntes vi hadde gått skuffende tregt.

Samtidig som vi advarer hverandre mot ikke å bli «grumpy old guys», registrer jeg at medlemmene har lett for trekke frem negative sider ved nyvinninger. Et eksempel er den imponerende kartleggingen av det humane genom, noe som åpner for at vi i nær fremtid kan screene hele befolkningen for grad av sykdomsrisiko. Ikke bare vil det øke den generelle sykdomsangsten blant folk, noe Dagbladet og VG nører godt opp under, men det kan også føre til enda flere kostbare og unødvendige kontroller av friske personer.

Et av medlemmene hevdet at vi $i$ vår tid har fått en betydelig endring i lege-pasientforholdet. Det har skjedd gradvis, nærmest som en stille revolusjon.
Fra et paternalistisk system der legen hadde all makt, og pasienten var en passiv og lydig mottager, er i dag lege og pasient blitt mer likeverdige. To eksperter møtes - den ene kjenner sykdommen, den andre hva det vil si å ha den. Som Ibsen helt riktig påpeker: «Det er ikke greit å forstå hvor skoen trykker når en ikke har den på.» (1). Pasienter har dessuten fătt et langt større ansvar for egen helse. Vår rolle er ofte å gi hjelp til selvhjelp.

I doktorklubben har vi én kirurg. En utmerket håndverker, for øvrig. Hans uærbødige påstand er at kirurgene helbreder, medisinerne må nøye seg med å lindre og trøste. Dette har visstnok særlig gyldighet for nevrologer og psykiatere.

Ved en skjebnens ironi fikk han for en tid tilbake isjiasplager og så seg da nødsaget til å konsultere en nevrolog. Det opplevde han som ydmykende. Vi forsto at dypere gikk det ikke an å falle. Da minnet et av medlemmene ham om Johan Torgersen, vår anatomilærer på doktorskolen. Han hevdet nemlig at «intet har falt så dypt som testiklene». Og så føyet han gjerne til: «Men man kan godt være mann selv om testiklene ikke henger mellom knærne.»

\section{Karl Otto Nakken \\ karln@ous-hf.no}

Litteratur

1. Ibsen H. Peer Gynt. Et dramatisk dikt. København: Den Gyldendalske Bokhandel (F. Hegel), 1867. 